\section{investigações criminais}

\section{Miguel Simão}

Escrever tem alguma coisa de tridimensionalidade, às vezes você nem escreveu uma frase e já está ali pairando no ar esperando pra ser encaixada.

\section{n.1}

(publicada em 18 de fevereiro|2014)

Vi a exposição da Raquel Nava e André Santângelo. Ambos tiram partido da fotografia pra fazer coisas bem além desta técnica. $\bigcirc$ André constrói paisagens magnificas, surreais fazendo fotomontagem. Ele carrega na dramaticidade, eu diria religiosa. A Raquel usa a foto pra capturar situações plásticas montadas, mas não é só um registro, quando ela clica o escracho e o humor se revelam nos limites impostos pela bi-dimensionalidade da foto. Gostei do que vi.

Lá no Objeto Encontrado. 


\section{n.2}

(publicada em 20 de fevereiro| 2014)

Fui ver hoje a exposição "À sua saúde" no Museu da República com curadoria da Polyana Morgana. Lá vi obras muito interessantes nas duas salas que compõem a mostra. Figuras de peso na arte brasileira, alguns vão muito além, são artistas do circuito internacional como o Cildo Meireles e a Adriana Varejão. Na sala menor as intensões curatoriais ficaram mais claras, com um número menor de artistas e de obras. Na sala maior, hall do auditório, a curadoria continua com grandes artistas inclusive os locais, Milton Marques e Raquel Nava, mas enfraquece as ligações e a linha mestra se ramifica em vários caminhos. Nem opostos e nem tão distintos, mas vários caminhos. $\bigcirc$ fato não compromete a exposição, ela continua com peso e pompa até o fim. Entretanto, a culminância da exposição está reservada, propositadamente ou não, para um único artista; Bispo do Rosário. Artista que não é nem local, nem internacional e tão pouco é o que chamaríamos de saudável. Mesmo porque arte nada tem a ver com saúde. A arte é, bem ao contrário, a fronteira entre dois mundos: o da saúde e o da verdade. Grandes, Bispo do Rosário e José Eduardo Garcia. n.3

(publicada em 8 de março|2014) De Curators - eróticas

Ontem tive uma noite maravilhosa lá comercial da 412 Norte. Fomos agraciados com um ato de generosidade e de doação das mais legítimas e sinceras que já vi. A cidade ganhou um espaço fantástico dedicado exclusivamente à arte. Não é uma simples galeria, é muito mais que isto, é uma obra continente de outras obras. Se eu entendi direito a proposta, anuncio que vem por aí um modo muito interessante de mostrar e vivenciar as artes plásticas. A obra-galeria acontece no transcorrer do tempo, sem interrupções ela vai agregar, desagregar, somar pessoas, ideias, pensamentos, ações e muito mais. A Gisel Carriconde foi magnânima com a realização do seu sonho e transbordou a dádiva para todos nós. Parabéns !!! Depois eu vou falar sobre as obras e as artistas baixinhas e maravilhosas que estão expondo. 
n.4

(publicada em 29 de março|2014)

Decurators, apresenta Ingrid Barros e Karla Testa

Saí à francesa, não tinha outra forma. A festa estava boa, muito boa. Eu não conhecia quase ninguém e quem eu conhecia estava trabalhando naquele momento. A moça (Karla) da performance musical arrasou, swing, bossa e equipamento digital de primeira ordem. A outra moça (Ingrid) fez três seções de performance da tulipa [para espumante] sem a haste e a base, use a sua imaginação para ver o objeto. A performance deixou-me sem fala.

Sua atuação foi progressivamente importante, este tipo de trabalho tem um problema: quem não viu dançou, nunca mais verá. Não tem foto, nem vídeo, que dê conta do acontecimento no pretérito perfeito. n.5

(publicado em 30 de março| 2014) Noturno Soturno, Alfinete Galeria

Leitura de insone.

Um castelo flutuante de longas raízes igualmente flutuantes que dão alguma verticalidade a obra de dominante horizontalidade da ponte levadiça feita de tábuas que de tão frágeis vergam sob o seu próprio ausente peso seres diminutos quase humanos desertados nas bordas abissais da ponte estiada que vai dar numa rua muito real iluminada por uma luz vermelha que mais aquece a cena que propriamente ilumina no lado oposto um coelho sereno sentado sobre um pier-pipe celestial porém nada flutuante olha sabiamente o crânio que nos interroga com mil olhos concretos antes de vermos o que realmente temos que olhar o par de olhos

ausentes da caveira engraçadinha mas que mesmo assim nos diz o que toda caveira insiste em revelar nestas situações. 


\section{n.6 \\ (publicada em 4 de abril|2014) \\ Espaço Piloto - UnB Plano Expandido \\ Isadora Dalle, Ananda Giuliani e Samantha Canovas.}

A exposição estava ótima, eu acompanho estas moças já faz um tempo. Eu diria que poderíamos ter um subtítulo ou um adendo ao título escolhido por elas para qualificar a exibição como um "Tributo ao Neoconcretismo". Há na apresentação um evidente diálogo com esta tendência muito importante da história recente da arte no

Brasil. As três questionam os meios, os suportes e a não representação e se utilizam deste questionamento como motivação e forma de ação poética. Faturas apuradíssimas e em todos os trabalhos há uma denúncia de quebra de fronteiras entre o Bi e o Tri, plano expandido em multidireções. Tem muito mais

coisas a serem ditas, espero que outros colegas se manifestem também. A Isadora foi prejudicada nos trabalhos menores (pequenos

formatos), as sutilezas das marcas pictóricas/relevos sobre o papel estavam também na parede da galeria. Parabéns meninas, ousadia sempre!

\section{n.7}

(publicada em 5 de abril|2014)

Elefante Centro Cultural: Rita de Almeida

Quando eu saio por aí investigando exposições eu não estou atrás de novidades simples e puramente, quem gosta de novidade é o pessoal da indústria cultural e entretenimento. Eu quero consistência e poesia genuína. Não me importa se é tradicional ou não, tem que ter bossa e um grau de marginalidade mesmo que latente. Foi o que eu vi hoje no Centro Cultural Elefante. Está lá à mostra a Rita Almeida em dois momentos: na sala principal estão as suas colagens delicadas e escorregadias, noutro cômodo, num quartinho vangoghniano uma instalação que eu definiria melhor como uma ocupação. De fato ela morou lá alguns dias e é donde eu vou no meio da semana para me deitar por uma hora e tentar acessar as cicatrizes gráficas que a Rita deixou por lá. Este Centro Cultural eu não conhecia, mas o espaço expositivo era a casa de um casal sensacional que fez muitas boas festas ali. $\bigcirc$ espaço fica num beco e está muito bacana, vale uma visita. Tem também um artista expondo na sala do primeiro andar, eu gostei muito do que vi. São pinturas sobre blocos de concreto, nuvens e paisagens brasilenses. Há uma bela contradição da pintura de tema etéreo com os suportes de massa bruta, alguns deteriorados. Ele é o Matias Mesquita, ele se definiu como artista e investigador de processos. 
n.8

(publicada em 13 de abril|2014)

Caixa Cultural Aleijadinho e a Lâmpada Maravilhosa

Não vou fazer as minhas observações sobre a exposição presente, desta vez eu gostaria de fazer uma manifestação, tardia é verdade, mas imperativa pra mim: referir-se a este homem pelo apelido de "aleijadinho" sempre foi, sob o meu ponto de vista, um grande e irreparável erro. Por ter sido acometido por várias doenças, sífilis e outras mazelas venéreas, muito comuns e incuráveis na sua época, estas deformidades e sequelas decorrentes não thes atribuíram nenhuma qualidade escultórica diferenciada ou acrescentaram algum predicado ao seu talento como arquiteto e construtor que era. Do mesmo modo que ligálo insistentemente à cultura da pedra-sabão também configura uma perda de potência da obra deste grande escultor. Ele foi, sobretudo um brilhante criador de imagens entalhadas em madeira, modeladas no barro, projetista de prédios, ambiências de igrejas, pontes, prédios e fez também inúmeras outras incursões arquitetônicas. A esteatita (pedrasabão) é abundante naquela região de Minas. Material construtivo por excelência foi usado largamente na arquitetura da época por vários outros construtores e arquitetos. A construção do mito do "aleijadinho" me parece muito falha e provinciana e que os autores contemporâneos infelizmente cristalizaram com a publicação de livros e teses de doutorados na segunda metade do século $X X$. Antônio Francisco de Lisboa é muito maior do que o mito do "aleijadinho" e sua obra tem potência de sobra para figurar no mundo todo. Talvez fosse melhor chama-lo de "O Aleijado", título muito mais afinado com seu poderoso trabalho.
$\mathrm{Na}$ exposição eu chamo a atenção para uma inesperada e intrusa instalação duchampiana: ela consiste numa porta em que você olha pelo buraco da fechadura e vê uma cena insólita do artista esculpido. A proposito disto, eu gostaria de lembrar que o Aleijadinho foi um grande artista das instalações, ainda que religiosas é verdade, pois todas as suas grandes obras eram para site-specific. Que danado, antecipou a coqueluche do século XXI! 


\section{n.9}

\section{(publicada em 3 de maio| 2014) \\ Patrícia Bagniewski - Fim de Festa}

Venho acompanhado o trabalho desta moça pelas imagens mostradas aqui no FB. Todas as vezes que ela aparece soprando ou manipulando a massa incandescente de vidro eu tenho uma ótima sensação, embora sejam meras fotos. Acontece que eu tenho conhecimento das artes do fogo e complemento as informações da foto com as minhas próprias memórias. Realmente tive uma expectativa grande com a mostra da Patrícia. Fui lá conferir, todos deveriam fazer o mesmo. Entretanto, considero que houve um atropelo dos seus delicados vidros soprados.

Os objetos fabricados em madeira compensada não têm potência necessária para apresentar e dialogar com os frágeis frascos de ar. Bem como as ampolas e os balões vítreos não se prestam à narrativa dramática como é sugerido pela montagem da instalação. Imagino que faltou acreditar nos

próprios objetos enquanto entidades atemporais, dotadas de grande encantamento e mistério aos olhos de todos. Por que não uma simples exposição? Imagino também que uma fonte de alto calor para lembrar que o vidro é feito com combinações de forças naturais poderosas: terra, fogo e ar que é a mesma receita para fazer o mais puro aço. Três exposições e um show em plena segunda?!?
Eu ando por aí procurando criminosos, criminosos da arte! Quero ver quem mata a cobra e mostra o pau! A Clarice Gonçalves Lima tem uma obra chamada "Foda" que é um crime violento, desconcertante e é uma simples pintura. Está na sala do primeiro piso da sua exposição individual no Centro Cultural Elefante. Tem mais um ou dois trabalhos de tirar o fôlego. Já o Rodrigo Paglieri e o Alexandre Rangel fizeram a quatro mãos um vídeo muito bom onde o planeta Terra, na sua metade sul, é transformado numa panela de feijoada. Se não me engano o título é "Pangeia" onde as placas tectônicas são fatias de calabresa e linguiça portuguesa, hilário e muito significativo, esta lá no CCBB. É uma mostra individual do Rodrigo. Lá no Espaço Piloto tem um menino artista avulso que fez um vídeo muito interessante e nervoso, bastava isto para sua participação no evento. Vale a pena ver um vestido muito costurado e bordado tragicamente, obra de uma artista muito silenciosa que é quase uma clandestina, a Rita Almeida. Tem também os poemasplásticos-visuais-(?)-pré-escritos do Léo Tavares. Aquele trabalho com as horas carimbadas e seguidas de sentenças curtas (apropriadas dum livro), coladas: é muito bom e ficaria bem na minha casa. Tem outras coisas e pessoas que eu não citei, mas é que eu fui a um show no Feitiço Mineiro e ouvi novamente "na capela" Eduardo Rangel fez com a música "Mamãe coragem" do Torquato Neto, eu amo esta música, e de quebra ouvi também de Sergio Sampaio "Eu quero é botar meu bloco na rua ...". O Rangel, muito bom intérprete, foi muito bem acompanhado do guitarrista monstro Haroldinho Mattos, então fechei a noite e minha cota de moço investigador e bom samaritano. 


\section{n.11 \\ (publicada em 17 de maio|2014) Renato \& Rodrigo}

Fazer pintura e desenho a quatro mãos por

princípio não me seduz muito enquanto possibilidade de criação, embora o resultado possa ser bem bacana. Nesta exposição temos

alguns belos momentos desta parceria, sobretudo nos pequeninos formatos de inspiração mais lírica, figuras esvoaçantes, flutuantes à la Chagall. Os dois rapazes ficam produzindo na própria galeria durante sete dias - imagens na cabeça e pincel na mão. Nenhuma pirotecnia e nem grandes gastos, só pintura na sua sacrossanta tradição. Mas não para por aí, conversando com o Renato ficou claro pra mim que esta situação de trabalhar a quatro mãos tem o seu viés político e também traz à tona questões de ordem éticas e estéticas relacionadas com a arte e a vida de modo geral. Perguntei sobre estas coisas todas: autoria, individualidade, comércio de arte, o papel das galerias, dos curadores e etc. Foi uma conversa rápida e muito amena, não nas ideias tratadas, mas na condução e no tom. Rodrigo \& Renato são dois gentilíssimos e autênticos poetas-plásticos. Passem lá pra uma visita, eles estão galeria Objeto

Encontrado 102 Norte.

\section{(publicada em 29 de maio|2014) Espaço Piloto VIS/IdA/UnB Um por Todos e Todos por Um}

Fui lá conferir as exposições, no post do FB dizia haver uma sobreposição de duas exposições. Entretanto, ficaria mais fácil dizer que na verdade se trata de uma única exposição com vários expositores, ou seja, uma coletiva. Pareceu-me que houve tentativas de criar um desenho de montagem que fizesse ligações entre uma obra e outra a fim de criar um eixo plausível de leitura. Talvez

se as obras que estão na Galeria Mezanino fossem participantes da exposição da Galeria

Térrea e vice-versa, teríamos uma mostra coletiva mais rica. Não acho interessante criar simetrias onde elas não existem e nem forçar aproximações pouco críveis a fim de criar um texto curatorial ou fazer uma resenha jornalística. Afinal trata-se apenas de pinturas e desenhos de vários jovens autores todos em busca de solucionar as suas questões. Neste caso eu diria que para cada cabeça uma sentença. 


\section{n.13}

(publicada em 7 de junho| 2014)

SP Arte Brasília "Nós vamos invadir sua praia"

Só tem figuras do entre-guerras, do pós-

guerra e os monstros do neoconcretismo

brasileiro. $O$ que era pra ser uma feira para

grandes negócios terminou sendo uma bela

exposição de coleções privadas. Vi o Sergio

Camargo e lberê muito bons e também vi

outros tantos artistas que eu admiro, nisto foi

bom. O perfil da feira é bastante conservador,

ela se garante nos nomes já consagrados e

com indiscutível valor de mercado. Esta feira é

para adultos e quem tem voz ali é o galerista,

não tem lugar pra crítico e nem artista, no

máximo um decorador pode também cantar

de galo neste chique evento. Gostei da

solução espacial e das bebidinhas rolando de

grátis, entretanto conversando com alguns

galeristas, todos muito gentis, ficava clara a

decepção com o público brasiliense

caracterizado como inculto e pão-duro. A feira

usa um espaço contíguo a aquele setor do

shopping onde estão as grandes marcas da

moda internacional. $\mathrm{Na}$ tarde de ontem a feira

esteve jogada às moscas, enquanto isto as

madames não paravam de comprar sapatos e

bolsas e outros mimos ali ao lado, os maridões

endinheirados ainda não sabem o quanto as

obras de arte são bons ativos financeiros.

Muitos deles vão morrer sem saber e suas

mulheres no fim da vida terão centenas de

pares de sapatos num armário embolorado.

Vou propor a comunidade artística para

criarmos uma feira cujo nome seria BR Arte (-)

SP e (-) RJ, pois estes dois polos não permitem

o florescimento de mais nada no Brasil,

inclusive novos mercados de arte.

\section{n.15 \\ (publicada em 14 de junho| 2014) Galeria Alfinete: Ação afirmativa, múltiplos e \\ derivados.}

A ideia é muito boa, não estou falando de arte, mas sim de sobrevida do artista, pessoa que come, dorme e necessita de se abastecer de vários itens como qualquer outro ente. Comprar uma obra da Andrea Sá (Capi) por alguns trezentos reais é muito bom para o comprador, mas se ela vender vinte destas peças será muito bom pra ela também, espero que ela venda tudo. Eu e minha companheira

compramos a 1/20 e eu nem posso esperar para colocá-la na minha casa, entretanto só na quinta-feira vai rolar, pois é o final da exposição. Lá tem muito mais, a obra do Gê Orthof é linda e a do Milton Marques é muito instigante. Embora a mostra tenha este viés da comercialização o que se vê é uma bela exposição coletiva que prima pela simplicidade e delicadeza persuasiva das obras expostas. Parabéns para a Alfinete Galeria pela iniciativa. 
Tomar decisões e ter opiniões que envolvam pessoas queridas e/ou colegas é sempre muito difícil, mesmo que os aspectos positivos sobressaiam há sempre aquele ponto ou outro que não irá se encaixar como o esperado. Isto acontece mais a miúde comigo do que eu desejaria. Pessoas muito aceleradas como eu acabam andando na frente e atropelando quase todo mundo. Não acho graça neste comportamento, mas é muito difícil evitá-lo uma vez que há uma apatia generalizada em quase todos os setores da vida contemporânea. Então pessoas mais entusiasmadas roubam para si os princípios do movimento. Esta falta de concorrência não é muito saudável e é cansativa para quem se dispões amorosamente (ou por compulsividade) a acionar os mecanismos. Não pude ir a nenhuma exposição ou evento cultural nesta semana, outros compromissos inviabilizaram as minhas investigações. Senti

falta, mas por outro lado a pausa me faz analisar esta minha auto-atribuição de comentador da criação alheia. Já recebi algumas confirmações de que estes escritos têm boa acolhida pela comunidade, mas também já tive notícias de ter criado um ou outro desafeto justamente pelo escrito ou pela falta dele.

Eu comecei a fazer estas investigações via FB justamente por entender que as artes plásticas aqui no DF estão muito concentradas nalguns seguimentos muito estanques e autofágicos.

Além disto se percebe que depois do vernissage parece que a exposição nunca existiu.
Ninguém diz mais nada sobre o evento, não há um retorno para o artista, ninguém faz uma critica ou qualquer outra manifestação. Os jornais, as TVs e a própria universidade não se sentem na obrigação de produzir qualquer tipo de pensamento sobre estes acontecimentos tão importantes pra vida cultural da cidade. Diante disto eu então resolvi ocupar parte deste espaço ao menos aqui na pracinha do FB. Eu tenho gostado de ir num evento e depois pensar sobre ele para escrever ou não. Dou preferência de publicar sobre jovens artistas, pois sabemos quanto é difícil se expor no começo da trajetória e o quanto é frustrante o silêncio que se segue. Não me considero no papel de crítico ou qualquer outra designação semelhante, sou apenas um escultor que tem entusiasmo para falar de arte e sobre arte produzida aqui neste caldo brasiliense. A indiferença não faz parte das minhas vocações e para firmar esta característica eu prefiro pecar pelo excesso de participação a pecar pela falta dela! 


\section{n.17}

(publicada em 1 de julho| 2014)

CAL - Galeria Acervo Casa da Cultura da América Latina Neste mar tem muitos rios

Gostei e rever a Galeria Acervo CAL-UnB, foi na minha gestão de Coordenador de Galerias que este espaço tornou-se integrante do complexo CAL para mostras contemporâneas. Achei que a exposição presente está bem aninhada ali na singeleza da sala de pé-direito não muito alto, piso de taco de madeira peroba do campo - uma raridade hoje em dia e os nichos arquitetônicos que revelam vestígios de antigas paredes que foram demolidas para integrar as salas do espaço expositivo.
Conheço estes jovens que estão na mostra, é muito fácil trabalhar com todos eles, pois são muito comprometidos com o que fazem tanto no plano dos estudos - são todos estudantes de arte na UnB - bem como na práxis da arte. São requintados na fatura, mesmo que obras não demonstrem nenhuma vocação para o virtuosismo tradicional, mas dialogam com a virtuose do mínimo, das pequenas ações e das diminutas e cruciais decisões. Escolheram referenciais históricos muito próximos, isto ajuda muito na ocupação do mesmo espaço por tantas personalidades sem haver choques frontais, porém, se distinguem o suficiente para não permitir a monotonia que às vezes se impõe nas mostras formalistas, sobretudo nas individuais. Não diria que esta rapaziada esteja fazendo questionamentos nos moldes do neoconcretismo e outros movimentos do pósguerra, mesmo porque neste aspecto não há nenhuma novidade na exposição, vejo mais como um tributo cheio de bossa a vários grandes artista e alguns recortes cruciais da história da arte recente, a brasileira e a de outras praças mais internacionais. A exposição pode e deve ser vista com generosidade pelos mais experientes, que já viram tanto, e pelos mais novos o olhar deve ser inquiridor como sempre, mas é importante observar como a arte deve procurar filiar-se para chegar ao mundo e se fazer escutar. Parece-me que estes meninos e meninas sabem por onde estão andando e aonde querem chegar. Estou na torcida. O título do texto foi concebido a partir da obra da Isadora 


\section{(publicada em 2 de agosto| 2014) Lis Marina Maneira Negra}

Não sei se todos conhecem esta técnica de gravura em metal chamada Maneira Negra, ela se constitui basicamente nas seguintes ações: primeiro o artista grava um preto intenso e aveludado em toda a extensão da chapa de cobre. Depois, com a ajuda de instrumentos específicos, ele vai sacando a luz por raspagem e brunimento para construir a imagem desejada, é lindo e mágico este processo. Pois é metaforicamente assim que a Lis constrói as suas fotogravurasfotos, eu imagino. O negro profundo domina toda a composição e a partir dele surgem valores infinitos de cinzas até chegar à branca luz do papel revelando formas nada fáceis para se descrever, aliás, eu nem vou tentar fazê-lo. $\bigcirc$ que eu posso dizer é que estas imagens são do mundo dado, mas são fugidias e nos propõe dúvidas acerca da natureza que as constituem, ora são pedras, noutras são madeiras, mas ainda podem ser ossos, inclusive ossos humanos, o que é muito instigante. A exposição não está numa galeria e sim numa passarela do primeiro piso da Livraria Cultura, porém isto não compromete em nada a mostra e em minha opinião até colabora com a apreciação das obras. 
Invasores do espaço (O INÍCIO)].

Como sempre ele estava ricamente vestido e com inumeráveis adereços cuja simbologia me escapa completamente, porém plasticamente é muito atraente e compõe bem o personagem da gueixa-homem- descalibrada. Ele realizou uma performanceparódia da criação do mundo com direito a ETs, OVINIS, robôs e música épicatriunfal. Foi muito engraçado ver a personagem interagindo com um Drone, o operador foi preciso nos movimentos, não houve falhas na relação homem/máquina. Mas na narrativa proposta pelo Quintão aquele drone representa um OVNI que traz a identidade para a humanidade simbolizada numa máscara que chega do céu, assim eu li o drama. Ontem eu ri muito com a irreverência do artista em combinar coisas tão distintas como alta tecnologia e ritos medievais, entretanto fiquei pensando sobre estas máquinas voadoras. Hoje, se eu pensar muito, eu devo é chorar, pois em Bagdá neste momento tem vários destes drones cruzando o céu, fazendo varreduras na Terra e arquitetando planos nefastos. Logo virão outros deles equipados

\section{n.21}

(publicada em 31 de agosto| 2014)

Criacionismo Tecnológico - Madame Quin Quin

Ontem a noite estava bem fresca, fui eu e a minha companheira ver a programação da Galeria DeCurators - Dança para Tela, tudo ao ar livre. Vi vários vídeos interessantes e uma exposição fotográfica de registros de performance acontecidas ali naquele espaço. Depois, bem mais tarde, quando muitos já haviam ido embora, aconteceu a performance do Rogério Quintão Madame Quin Quin [Congelados no tempo: com armas e bombas. Não fazem nada de divertido, estes drones realmente são alienígenas e muito mal intencionados, pois querem levar sofrimento pra aquela humanidade criada entre os rios Tigre e Eufrates há milhares de anos. Querem aniquilar a história pra emplacar a sua desumanidade que vem camuflada em divertidas tecnologias. Estes alienígenas vem do mundo chamado Kapital que fica na constelação IndiferençaAbsoluta e eles não medem consequência pra manter intactas a suas provisões de Nutella. 
n.22

(publicada em 3 de setembro|2014)

Espaço Piloto Ida Vis UnB Raquel Nava [Ihas]

Meu querido Matias Monteiro mil desculpas, mas eu não vou ler agora o seu escrito a respeito da presente exposição no EP sobre a Raquel Nava, eu vi que tem até bibliografia ao final do texto, deve ser algo muito sério e importante, pois vindo de você eu não tenho dúvidas disto. Entretanto, eu vou dizer algumas coisas sobre a Raquel na condição de simples fã e apreciador da sua obra, mas não só da produção plástica apresentada aqui nesta exposição. Rotineiramente eu vejo as instigantes postagens desta artista no FB. Algumas delas são extraídas da sua própria produção, enquanto outras são garimpadas na internet e apresentadas pra nos deliciar com a ousadia e o humor cáustico dominante nestes posts. Mas não se enganem, pois todos são iniciadores de processos reflexivos muito importantes. Ela atua no mundo virtual de maneira semelhante ao seu modo de agir no mundo corpóreo e matérico. Ela se apropria do mundo dado com muita liberdade e ousadia, revira tudo e arrasa quarteirões da lógica e destrói sem dó lugares comuns. Uma vez que ela tomou pra si algumas práticas (outrora tímidas) de algumas vanguardas do no século vinte, ela não precisa mais de citações e nem licenças poéticas, pois ela sai batendo firme e delicadamente como se tivesse inventado todas estas ações aqui e agora de tão vitais que são as suas criações poéticas. Em minha opinião é justamente ai que reside a sua força e potência criativa. A Raquel Nava jantou, almoçou e bebeu a arte ocidental e tudo que sai dela agora tem os vestígios disto, principalmente as farpas, fagulhas e a ironia, redentora nestas latitudes. 
n.23

(publicada em 10 de setembro|2014)

às 16 horas de uma quarta-feira quente e com $20 \%$

de umidade Alfinetadas

Hoje de tarde eu resolvi vagabundear um pouco, fui numa barbearia que eu vou sempre e fiz bigode, barba e cabelo. Depois fui à Alfinete Galeria ver uma rapaziada que eu gosto muito, todos engajados nos processos da arte e alguns deles também trilhando o caminho da academia. Chegando lá descobri

que havia mais uma sala de exposição, eu fiquei feliz com a expansão do projeto original, sinal de que as coisas vão bem para o proprietário e, por conseguinte, pra nós artistas e apreciadores das artes plásticas. $\bigcirc$ espaço já é um lugar especial, sobretudo nas aberturas que ocorrem aos sábados bem de tardinha, na boca da noite. Quando eu chego dou de cara com o Pop-lírico do Ralph Gehre na parede externa da galeria, é sempre bom ver este homem doando obras assim com data prévia pra extinção, pois no mês que vem outro artista em trânsito vai se jogar naquela mesma parede. Eu ainda não experimentei ser um artista-bomba, só no FB que eu explodo todo dia, mas com palavras. Depois disto eu entrei na Galeria 1, foi difícil preu tomar pé da situação. Parecia que eu tinha chegado à festa errada, não reconheci ninguém, mas também ninguém nem sequer olhou pra mim. Não tomei nenhuma bebida e fui embora atrás da minha turma. Na nova galeria da Alfinete

Galeria, propositadamente em ruínas, encontrei mais cinco artistas e um texto de meia lauda. Neste caso eu preferi sair da

galeria depois de ver rapidamente as manifestações em variadas mídias, pois estava muito quente e desagradável o local da experimentação da rapaziada.
O texto é o que há, não sei se foi escrito por todos ou por outra pessoa de fora, mas eu diria que facilmente ele seria confundido com o texto do curador chefe da

BienallnternacionaldeArtedeSãoPauloDokumentaVeneza. A futura galeria deve ter no máximo $30 \mathrm{~m} 2$, é pequena demais para caber tanto texto assim. Acabei a primeira investigação e fui pra segunda, mas o Elefante Centro Cultural estava fechado, foi uma pena. Continuei vagabundeando sem destino algum. 
n.24

(publicada em 12 de setembro| 2014)

Noite selvagem com elefantes e piranhas.

Noite de sexta pra um homem casado e com filho pré-adolescente geralmente significa uma saidinha, pizza, uma cerveja discreta ou um cineminha. Ontem eu quebrei o protocolo, a minha mulher me deu uma carona até o Elefante Centro Cultural - 706 Norte preu ir num vernissage. Ela parou o carro bem junto a

três meninas vestidas de micro saia e tope. Todas elas estavam sobre sandálias plataforma $15 \mathrm{~cm}$, esta peça do vestuário deve ser muito importante pro trabalho delas, embora eu não saiba exatamente o por quê. Todas me paqueraram ostensivamente e eu passei por elas mais ou menos tímido, mesmo porque minha mulher não arrancara com o carro como de costume, desconfiada ela ficou observando por um tempo, acho que ela tentava entender as minhas intenções, imaginei. Por força das circunstâncias eu segui direto para o beco donde fica a galeria, fui ver as exposições de dois artistas uruguaios a Elián Stolarsky e o Victor Lema Riqué. Tudo que vem do Uruguai hoje me interessa, pois o presidente Mujica é o meu guru, é meu Dalai Lama político. Ainda vou propor campanha pra ele virar presidente da América Latina ou quem sabe da Terra, por

que não? Pois bem, os dois artistas participaram de um projeto de residência no

CCE, se não me engano ficaram por lá três semanas e o resultado desta vivência estava exposto desde ontem para nossa apreciação. Os dois uruguaios trabalham com os suportes e procedimentos tradicionais das artes plásticas, contudo ambos buscam falar ou se comunicar com o tempo presente e suas problemáticas.
No caso do Victor Lema Riqué ele constrói simulacros de paisagens urbanas muito duras e agudas usando de forma nada lírica o desenho com carvão, fita crepe e o papel branco. Ousado pela simplicidade e pelo manejo incomum destes materiais muito difamados e manjados na perspectiva atual. A obra é bastante ambígua, trafega entre a abstração e a representação muito sutilmente. Já a Elias Stolarsky tira partido de outra técnica muito tradicional que é a ponta seca (salvo engano) que ela usa na chapa de acrílico transparente. Pareceu-me que ela usa este recurso da calcogravura sem intenção de fazer impressão, ou seja, o que seria a sua matriz é na verdade a sua obra final, contudo elas estão entintadas de preto pra revelar com contundência o seu tema. Ela nos apresenta o trabalho de forma invertida, pois a parte gravada fica pra parede e isto cria uma embriagues na visão, confirmando a impressão de certa virtualidade das imagens, sendo elas digitais ou não. Ir neste beco, encontrar amigos e trocar ideias é sempre muito bom! Lá por volta das dez horas eu resolvi ir embora. Fui a pés pela W3Norte até o Martinica Café. No caminho encontrei vários outros grupinhos de meninas disponíveis e muito dadas. Rapaz, foi bom aquele desfile de cinco quadras, cheguei ao Martinica cansado e inflado, pois tinha tempos que eu não era tão paquerado. Obrigado meninas pelo serviço gratuito e pela simpatia elaborada! O setor de serviços de Brasília ganhou muito com a Copa do Mundo, notei isto naquela noite. 
Peguei o ônibus lá pelas 4 da tarde, tá fácil ir até a rodoviária de baú, pois eu moro $111 \mathrm{n}$. bem de frente ao ponto. Vou à galeria da CAL ver uma exposição de pinturas: eu gosto de ver pintura e gosto de ir ao SCS e bater perna. Pra quem passa o dia todo na Maquete-UnB ir ao centro torna-se um ótimo passeio, no meu caso há uma quebra total da minha amada rotina de escultor obsessivo. Além disto, eu vou lá também para matar saudades do próprio espaço, pois eu fui Coordenador de Galerias da Casa da Cultura da América Latina por dois longos anos. Para mim a CAL é a galeria melhor situada de Brasília, me dá preguiça de ir às galerias localizadas em ministérios, tribunais e outros espaços assépticos, galeria em shopping então nem se fala, tenho arrepios. O SCS lembra o centro de Sampa, muitos bares e lanchonetes todos cheios de homens bebendo cerveja em plena tarde de quarta-feira, dá até certa inveja desse desatino da embriaguez na hora do trabalho, ainda mais pra mim que estou no rumo da abstinência. O SCS não tem charme algum, é comumente muito sujo e não tem nenhuma loja que me interesse particularmente, mas mesmo assim é um bom lugar pra se sentir parte de um mundo maior e mais rápido do que a vida na academia. Pois bem, finalmente chegando à $C A L$ eu vi as telas selvagens da

Malu Engel, elas estão esticadas, como as peles para curtir, diretamente nas paredes da galeria, mas vi também dois nomes assinado o ótimo texto de apresentação: é o Léo Tavares e o Paulo Vega Jr. Eu, com a maior cara de pau, me aproprio das palavras deles pra acabar de falar sobre o que eu vi ali. 
n.30

\section{(publicada em 8 de novembro|2014)} Bia Medeiros, só e acústica

Fomos caminhando até o Centro Cultural

Elefante, a minha companheira ainda não conhecia o espaço. Nós gostamos das caminhadas, nisto nós sempre combinamos, sobretudo uma caminhada com esta possibilidade (que é raro em Brasília) de encontrar amigos, bater um papinho, ver uma exposição e voltar pra casa, é uma felicidade!

Mas felicidade também é ir ver uma mostra individual da minha querida amiga $\mathrm{Bia}$ Medeiros. É ela mesma, a mulher grupal, acolhedora e generosa se mostra lindamente e com muita simplicidade tipo: "um banquinho e um violão". Basicamente apresenta desenhos e neles suavidade, lirismo e a libido correndo solta, muito embora não tenha nenhuma cena de sexo rasgada e explicita.
Sexo e desenho tem correspondência direta, sobretudo no emprego de poucos recursos e

na economia dos meios pra buscar com sinceridade o que se deseja. No sexo às vezes precisamos de algum veneno e no desenho algum descuido precioso que faz toda a diferença, tá tudo ali. Lá tem palavra sim, porém quem comanda são as cores e as linhas e principalmente não há vestígios de outras mídias mais eloquentes presentemente. Tem quatro décadas de pensamento plástico, mas não é uma retrospectiva, é presente mesmo e é inédito. Saindo de lá eu e minha companheira, voltando pra casa, seguimos pela W3 rumo à SQN 111 donde moramos, no caminho passou um carro por nós e o carona gritou "suas piranhas ". Olhamos em volta e realmente foi dirigido a nós a chamada do rapaz esfomeado. Eu fiquei imaginado; a minha mulher é bem bonita, feminina e podese dizer gostosona, mas e eu? Será que este cara realmente achou que eu fosse algo que ele desejasse? Depois lembrei de ter visto um plástico do Aécio no vidro do carro, conclui que ele não queria sexo, era apenas um coxinha FDP com saudades da mãe dele. 
n.31

(publicada em 10 de novembro|2014) A Nova

Referência Galeria de Arte + Gê

Depois de três tentativas frustradas eu

finalmente achei a Referência. A nova versão

da galeria é pequena, mas tem bossa e uma

vista muito agradável para as alamedas da

quadra residencial. Creio que a CLN 205/206

tem vocação pra galerias e outras atividades

culturais, lá é uma espécie de centro velho ou

zona das docas aqui de Brasília, eu morei anos na SQN 205 e sempre tive esta miragem. Tem escola de música, teatro, produtoras de arte, ateliês, sinagoga, cursinhos de pintura pra madames, templo evangélico e pets entre outras coisas nada triviais. Parabéns para a Onice e para o meu amigo Rosildete. Fui lá também pra ver a exposição individual do artista Gê Orthof. Entre desenhos e objetos tem uma instalação muito interessante que domina a cena e a pequena sala de exposição. A instalação é potencialmente explosiva como o assunto que ela trata. Esta é a segunda obra que eu vejo aqui em Brasília com o uso de milhares de palitos de fósforo, ambas muito poderosas e no limite entre um pacífico palitinho com sua grande utilidade e a iminência de uma danosa reação em cadeia. Para que se tenha uma ideia, o fósforo da tabela periódica (não o palito de fósforo) é o único elemento químico que não existe na atmosfera, se não unicamente quando encontrado em forma sólida nas rochas e ossos, ele deve ser guardado dentro d'água pra não entrar em combustão espontânea na presença de oxigênio. Esta é uma bela metáfora pra falar das forças que polarizam os vários mundos que vivemos e também daqueles sobre os quais ouvimos murmúrios e ecos distantes.
Está tudo por um triz! Já para ver os desenhos, lindos em suas cápsulas de acrílico, é necessário encontrar a distância correta para percebermos a obra como um todo. Se você guarda maior distância vai perder muitos detalhes importantes que são minúsculos. Contudo, se você aproximar-se muito para ver as minúcias da superfície o papel se agiganta tanto que você se perde como se estivesse numa campina imensa e plana. Depois de encontrada a minha própria e ideal equidistância, eu tive a sensação de ficar alternado entre um olho que vê o desenho e o outro que lê um texto, então por um triz eu consegui entrever brevemente aqueles mundos. Para apreciar esta exposição faz-se necessário algum tempo disponível. 
n.32

\section{(publicada em 15 de novembro| 2014)}

Hoje eu resolvi que iria a duas galerias pra ver e escrever um pouco sobre as novidades. Só consegui ir numa. Chegando ao Objeto Encontrado, antes mesmo de ver a exposição, eu encontrei um casal muito simpático e que com certeza iria render alguma boa conversa. Não deu outra, fui indo na onda do bom papo e quando vi já era tarde demais. Perdi a outra exposição, mas ganhei a noite confirmando, com quem entende, algumas observações sobre comércio de arte e seus atores aqui em Brasília. As conclusões da conversa todos já sabem, porém é sempre bom lembrar pra não ficar muito iludido, né não? Mas agora vamos falar da exposição. Bem, houve um tempo que a fotografia ameaçou o território da pintura, mas isto já passou e hoje cada uma das linguagens segue seu caminho, mas não impunemente e inocentemente, pois nestas pelejas poéticas os processos acabam se contaminando. As fronteiras se desmancham e se refazem continuamente, donde não há invasores e nem invadidos nestes territórios e front! O pictórico, o fotográfico e o gráfico trocam carícias nesta exposição do Pedro Ivo Verçosa. Logo na entrada tem um grupo de retratos muito interessantes, chegamos a pensar na solução fácil do computador com seus programas de edição fotos e similares, mas não, é um processo analógico para buscar a pintura usando fotografias. São simples sobreposições de imagens num suporte transparente. Novidades? Não, não há, entretanto tem o fundamental que a poesia, a fantasia e o encantamento.
Na sequência nos deparamos novamente com a fotografia, mas desta vez em preto e branco e tão fragmentada que só vale enquanto vestígio do que fora uma foto original, entretanto tem tudo que é necessário para um desenho e funciona como tal. Esta exposição fala dos meios e processos, mas felizmente fala também do próprio artista e das suas escolhas de como lidar com a criação nestes tempos com tantas mídias e arte-manhas disponíveis. 
n.33

(publicada em 23 de novembro| 2014) 0 pardal, o sofá e a arte da sobrevivência.

A arte contemporânea realmente nos libertou das grandes tradições ocidentais e não é de hoje! O que seria da arte brasileira sem a ruptura acontecida nos anos 50 e 60 ? Hoje muitos jovens colhem estes frutos de uma maneira muito tranquila, algumas vezes sem muita consciência histórica, mas está valendo o resultado. Na exposição que eu fui ontem na Galeria Decurators este fenômeno se repete. A opção dominante é do objeto, das instalações e da fotografia. Só havia um desenho, contudo este desenho foi o norte da expografia e das amarrações necessárias para se juntar tantos artistas e obras num mesmo local e gerar algum sentido. Uma aquarela representando um pardalzinho e um texto falando das características desta pequena ave exótica e ao mesmo tempo comuníssima em todo Brasil. Este bichinho é a cara do Marcel Duchamp, hoje nem mais sabemos que eles vieram pra cá nos porões das caravelas, todos os reconhecemos como um de nós sem necessidade de maiores explicações, palavra de índio!

\section{n.28 \\ (publicada em 10 de dezembro|2014) \\ Valéria e sua Pena}

Pois é, já fui muitas vezes à Hill House para ver o admirável mobiliário brasileiro contemporâneo: lá todas as peças são assinadas por seus criadores. Além disso, os objetos são manufaturados em madeira natural, com grande requinte e apuro técnico, por marceneiros muito habilidosos. Contudo, tenho também frequentado o local pra ver a produção de artistas plásticos brasilienses. Vi nesse ano os artistas-pintores Clarice Gonçalves Lima e Elder Rocha, em ambas as ocasiões o espaço expositivo se mostrou bastante adequado, ele cria um contexto muito bom pra apreciação das pinturas, pois mostra as obras numa ambiência caliente em oposição à frieza típica das galerias especializadas e também amplia o tempo de respiro entre uma obra e outra. Foi o que ocorreu ontem também na exposição da Valéria Pena-Costa. Os desenhos delicadíssimos e as colagens igualmente sutis demandam muito espaço-fôlego entre um grupo e outro de obras. Ao mesmo tempo, o apreciador deve aproximar-se muito de cada obra, pois elas são exigentes de intimidade e segredos. Não dá pra simplesmente traçar uma reta e ir sugando o néctar das obras como se elas fossem uma linha de montagem, afinal os desenhos tratam estritamente do feminino e o feminino não deve ser abordado tão bruscamente, por sorte temos que fazer um ziguezague oportuno induzido pela ambiência da sala. Vestidoluvaespinheiro me faz lembrar fábulas antigas e enigmáticas, porém como a imagem de cada prancha nunca traz o outro, não há entrelaço, não existem sombras, elas são solitárias e centradas, então me induzem a pensar que estas aparições são meio fábulas e ao mesmo tempo meio não-fábulas. Será que o que elas dizem é algo daqui e de agora? 
A arte esta por um triz! Este mundo é realmente hilário e isso é fato! Hoje eu fui ao Elefante Centro Cultural prestigiar a exposição donde participam como artistas alguns exalunos do VIS/IdA/UnB. Todos eles já estão pra lá de independentes e trilhando seus caminhos solo com brilhantismo e muita graça. O curador também é meu conhecido, cara estudioso e dedicado, ele é lá da UnB onde faz doutorado em arte. A festa estava linda e com muitos amigos ávidos de reencontros e trocas depois dos recessos de natal, ano novo e as férias de alguns. Até aí esta tudo de acordo com as normas, porém quando eu estava chegando ao beco que dá acesso à galeria, fui percebendo um número incomum de rapazes barbados, barbas grandes e nada sutis no desenho padronizado. Quanto mais eu adentrava mais barbados eu encontrava, de repente eu tive um estremecimento e se instalou uma dúvida deveras instigante na minha frágil mente: seria aquilo um fenômeno universal que começou em NY a cerca de oito meses? 
n.40

(publicada em 8 de fevereiro| 2015)

Alfinete Galeria 0 Paraíso de Derik Sorato

Ontem eu fui à Alfinete Galeria e era noite da galera mais jovem, mas nem por isso menos interessante. Encontrei $1 \mathrm{~kg}$ de alunos lá do VIS, entre eles encontrei o Rodrigo Cruz que estava estreando como curador. Este menino é um puta artista e pode muito bem desenvolver textos curatoriais com relevância e originalidade, pois ele é um inventor que corre riscos quando inventa - na obra plástica, performática e no texto - e isso é fundamental na minha visão. O outro garoto, mais jovem ainda, estava expondo desenhos na sala 02 sob a batuta do amigo e colega Rodrigo. Este rapaz está fazendo uma bela e surpreendente exposição. Diante do que vi na noite de ontem posso inferir que ele tem trabalhado muito e que deve ser um grande obsessivo como todo desenhista de bico de pena. Os desenhos do Sorato, no formato $\mathrm{A} 3 \mathrm{e}$ em preto e branco, são belos, simplesmente belos. São composições que tem grande rigor construtivo e ao mesmo tempo esbanja lirismo absolutamente informal. Suas aldeias ideais convidam ao sonho do bucolismo perdido, ele nos coloca olhando pra elas como se estivéssemos num balão, dá vontade de aterrissar e viver por ali, pois imagino que lá está cheio de pais, mães, irmãos, primos e amigos donde se pode brincar eternamente. Este paraíso será que é dele ou será que é meu?

\footnotetext{
* Na sala 01 tem outro rapaz expondo cujo nome é M. Gandhi. Eu não o conheci pessoalmente, mas dá pra perceber que ele conduz a sua verve poética pra outras belezas também possíveis. Contudo, não consegui adentrar sua poesia, embora tenha achado curioso os seus sudários feitos de gordos carrapatos esmagados.
} 
n.50

(publicada em 26 de fevereiro|2015) CCBB DF Wagner Barja Tumultua e Arrebenta

Anteontem rolou a abertura da exposição do Wagner Barja lá no CCBB-DF. Criador contumaz de adágios visuais cuja poética pontiaguda culmina na busca de diálogos com a história da arte, com artistas, com a política e outras várias questões que o auxiliem na boa reflexão sobre o presente. A ironia é sua arma tática por excelência, mas a economia de meios juntando com alijamento da artesania e a recusa das plasticidades sensuais são também outras características importantes da complexa exposição que nos espreita. $\bigcirc$ artista obedece aos rígidos protocolos das vanguardas mais radicais, nada de mimeses e outras representações deificadas, tudo é o que é. Ele, corajoso, deixa para o fruidor parte importante da amarração de cada obra, contudo esta coautoria não é pra todos, tem índices e prévias a preencher, por exemplo, não se deve perguntar quem é Beuys. A exposição não é fácil, mesmo o Barja, que tem enorme experiência de montagens e curadorias, deve ter sofrido para reunir todas as aquelas obras num só espaço. Elas recusam o diálogo umas com a outras, são autônomas, cada qual tem suas próprias questões que reverberam por todo o ambiente tumultuando a tradição de leitura típicas e calmas, eu sugiro que a visita seja intercalada com um cafezinho ou uma cervejinha, mas também pode ser outro veneno da sua preferência e gosto.

Não percam!

* Ainda tem o (nós)Jonas e a baleia, é lindo! n.51

(publicada em 8 de março| 2015) Culpada 0 segredo de Waleska Reuter

Afinal o que esta moça fez? Como nomear a sua proposição que aniquilou a então Alfinete

Galeria? Ela agora reina absoluta e habita sozinha aquela suíte branca e opressora. Não

é uma simples exposição de coisas instaladas, é sim a tomada radical daquele espaço, uma invasão bárbara à moda teutônica. É o máximo no mínimo, não poupou nada, nem grana e nem sonho, calculou milímetro por milímetro, ela abusou da retidão de boxeadora que lhe é peculiar.

Se de cara impacta a frieza do branco (de branco) para em seguida cairmos no intimista enigma do furo (espaço psíquico descomunal) sobre o altar limpo, porém assombroso, creio que num instante anterior ao que nos foi dado ver, durante a criação e no processo de construção houve com certeza uma orgia absoluta e excitação enlouquecedora, seja pela espera horrível da ação de outros atores

ou pelo júbilo dos encaixes perfeitos na materialização do imaginado. Fico tentando idear um roteiro de um filme de um só plano capturando esta moça, de dentro pra fora e fora pra dentro, nos sete dias anteriores à revelação dessa imolação de aparência tranquila. Daqui a trinta dias seu segredo irá ser sepultado pra sempre quando vier abaixo todo peso fantasmagórico do gesso, ornatos e candelabros prolixos que nem se quer iluminam o vermelho do sangue que obviamente está lá escorrido por todo o chão. (Homenagem ao dia das mulheres) 


\section{n.01}

(publicada em 21 de março|2015)

ForadasGalerias ( ${ }^{*}$ )

Yasmin Adorno e Raquel Nava

Estas duas figuras das artes plásticas das quais

eu sempre vejo publicações me dão muita satisfação, pois eu penso que elas sabem aproveitar bem o FB e experimentam os seus limites. Ambas o usam não como notícia ou simples comunicação, mas sim como potência poética, embora sejam de curtíssima duração pela natureza da mídia em questão, mas que, no caso delas, alcança boa amplitude e impregnação. Uma delas trata da pura beleza, aparentemente ela é clássica e conformada

com essa tradição, mas há sempre muito mistério e ambiguidade nas suas narrativas. Com suas imagens ela nos conduz a outros mares da sensualidade e nos dá a sensação de que por ali nunca navegamos. Talvez numa visitação de exposição convencional o seu trabalho seja ainda mais intenso, se for será mais importante ainda com a sua existência

factual!

A outra nos apresenta narrativas absurdas beirando o abjeto (são belos), parece que seu olhar aliado com seu poderoso desejo conspira pra que ela encontre o máximo possível dessas situações cujas imagens ela compõem e registra ou se apropria subtraindo-as do mundo consumado. No caso dessa artista eu já vi exposições e garanto que, embora sejam momentos diferentes, as duas formas de apresentação são potentes o suficiente para nos causar o sentimento de estranheza e interpor muitas questões.

* [ [(Esta nova modalidade de abordagem da arte me satisfaz e vai evitar confronto com os galeristas que não gostam de posicionamentos críticos sobre as exposições que realizam e as escolhas eles que fazem. Eu até os entendo, pois a arte tem o seu viés de negócio e ninguém gosta que se fale mal das suas mercadorias, mesmo quando não são lá essas coisas!)\}] 


\section{n.75}

\section{Culpado Museu Nacional da República DF - Galeria 2 -} Térreo Dr. Neo Son Maranavalhas

Eu estava na segunda sala da Galeria 2 apreciando o magnífico centauro biplano quando entrou no local, atravessando literalmente pela grande pintura, uma senhorinha de aparência enérgica e resoluta. Essa pessoa mal adentrou o recinto e já me fitou, ela me olhou firmemente e me fazendo sentir como quem foi pego em flagrante delito. Então ela vem na minha direção e diz: quanta criatividade não é mesmo? Tudo isso foi o meu filho quem fez! Você o conhece? Quanta criatividade e imaginação - repete a mulher sinceramente admirada e olhando ao redor, acima e embaixo. Em um minuto ela explica todo o processo da magnífica narrativa ali cuidadosamente instalada. Eu, logo eu que sou órfão-de- pai-de-mãe-e-de-curador, entendi tudo que se passava estando totalmente em imersão pictural com tal fundamental figura, contudo eu não gravei nenhuma informação objetiva vinda dela, somente ouvi a intensa voz do olhar daquela mãe glauberiana. É assim a exposição do Maraca, tudo é pintura-ficção e, inclusive, nós também o somos quando percorremos aquele recinto absolutamente virtual. Nele os elementos desgarrados do plano pictórico, alguns ainda ligados umbilicalmente às telas ou às superfícies disponíveis, ocupam assimetricamente, mas com hierarquias bem claras o mesmo espaço dos (ex)expectadores, tudo em prol da alucinante narrativa que o artista propõe ao exibir o ser humano de maneira tão jocosa e lancinante. Mesmo quando há um objeto mais robusto e em seu volume pleno a encarnação (barrocada) da superfície é determinante e empurra a estrutura interna -a materialidade factual- para o plano inferior, pois ali naquelas circunstâncias o domínio é da representação, pois até mesmo os objetos mais banais, emprestados e retirados do mundo, se submetem ao primado do simulado. Nada é o que é, pois esse artista que não tem nenhum temperamento tautológico - bem ao contrário. Uma ou outra lâmina de aço, duas imagens sacras e as velas de parafina acesas junto à parede são os únicos vestígios importantes que se mantêm íntegros nas suas respectivas funcionalidades originais. $\mathrm{O}$ artista estava presente ao menos uma vez em que eu estive na sala, diante disso eu arrisco ao dizer que são duas exposições; uma com a presença do artista e a outra na ausência. Estando lá dentro ele é o seu autorretrato encarnado e o provocador fundamental para que ao menos possamos tangenciar as simbologias e os enigmas, não obstante serem todas essas escritas pitorescas nossas velhas conhecidas, pois já são apresentadas ao longo de muitos anos nas fiéis mostras desse artista muito fundamentado na sua longa práxis. Por outro lado, na ausência do mesmo nos lançamos às nossas próprias bizarrices e nos apropriamos indevidamente daquelas criações atribuindo a cada signo as nossas intenções. Essa liberdade é coroada com a possibilidade de vivenciar o "nonsense" sem correr os riscos reais que o autor se submete nos mergulhos que faz na psique e na história humana. Entrei e saí da sala três ou quatro vezes, mas sinto que é necessário ir outras tantas, mesmo sabendo que os caminhos para a fruição são inesgotáveis e dependem do quão consciente está cada um do seu papel nessa grande comédia humana sobre a qual o artista brilhantemente nos conta e também donde ironicamente ele nos situa. 
n.76

\section{Circuito Artístico Brasiliense}

Ando meio ressabiado de escrever sobre arte, sobre a arte do outro principalmente, Porém, nesses últimos quinze dias eu vi várias exposições e hoje eu resolvi escrever algo.

Aliás, Brasília não tem dado trégua aos apreciadores de arte. Fui a Alfinete Galeria e me deliciei com as fotografias- desenho de

Evandro Salles, o conjunto da obra é impecável e pronta pra fruição. Contudo, eu acredito que os mais líricos ficarão a ver navios. Também vi nesse mesmo espaço, na parede externa, a obra de uma jovem artista

que insiste em correr grandes riscos e, inclusive, os de ordem estética o que é muito bom e raro nos dias de hoje, Ananda Giuliani. Quanto a exposição da galeria principal eu não tenho palavras, pois faltou-me um ponto de entrada pra compreensão do fenômeno plástico ali exposto. Também fui à Galeria Marcelo Henrique Lima pra ver o Taigo Meireles e suas pinturas. O Taigo corre por fora, não dá pra falar do trabalho dele, pois ele é o profissional dos pincéis e nessa seara eu não me meto, porquanto são métodos instituídos ao peso do tempo pretérito e estão muito além da minha competência técnica e também das licenças poéticas. Pra terminar o giro eu fui ao Elefante Centro Cultural ver o suor e o sangue do jovem artista Paul Setúball.

Pra um cara como eu, que sou sobrevivente dos primeiros anos da insidiosa doença que levou vários amigos, conhecidos e ídolos, não é fácil ver uma exposição toda feita de sangue.

Ainda bem que eu só soube depois de ter apreciado os belos desenhos sanguíneos. São desenhosfragmentos (pinturas também?) de objetos metálicos, de armas, bombas e também ferramentas.
Fez diferença saber que era tudo desenhado com sangue verdadeiro? Sim, pois nesse caso os desenhos, por um lado, ficam preciosos como ouro (por raridade) e, por outro, a narrativa de morte implícita em várias obras ganha característica de hiper-realiidade nas linhas singradas com o legítimo sangue bom do garoto em questão.

n.77

Alfinete Galeria Renato Rios Culpado Doces Laranjais do Doce Artista Renato Rios

Planícies Arvoredos Morrarias Cerrados Horizontes Caminhos Vastidões Céus Matas Montanhas Encostas Regatos Laranjais, esse é o nome do poeta cuja mostra de pinturas, de tão diminutas, não comporta nomes nem títulos individuais, não há como. As pinturas são feitas em cartões com as mesmas dimensões das etiquetas típicas de expografia.

Acredito que tenha ali naquela sala, lindamente trabalhada, uma centena de imagens - retangulares e redondas - que retratam quilômetros de paisagens externas e

milhares de anos-luz de visões internas da mais pura virtualidade pictural. Papel, telas, alguma tinta, pincéis e a poesia morandiniana

jorrando inversamente proporcional à modéstia dos meios, mas do que mais precisa um artista sincero?

* Noite linda com meus jovens amigos e amigas artistas, foram deliciosos encontros de muita leveza e graça. 